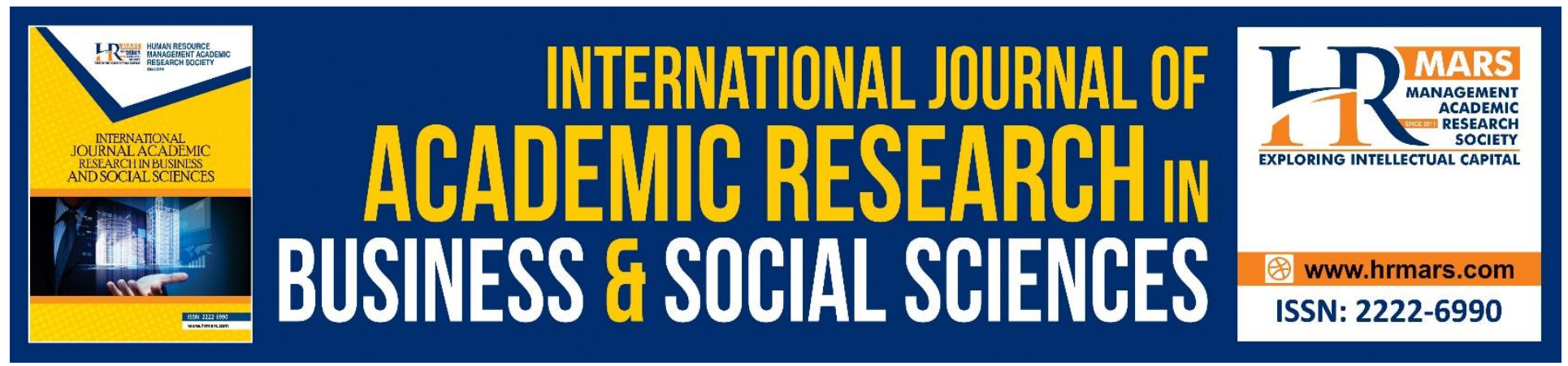

\title{
The Effect of Extra-Curricular Activities in Hizmet Movement Schools on Students' Personal Growth: A Case Study in Kurdistan Region, Iraq
}

Mustafa Altun

To Link this Article: http://dx.doi.org/10.6007/IJARBSS/v9-i2/5534

DOI: $\quad 10.6007 /$ IJARBSS/v9-i2/5534

Received: 02 Feb 2019, Revised: 17 Feb 2019, Accepted: 30 Feb 2019

Published Online: 03 March 2019

In-Text Citation: (Altun, 2019)

To Cite this Article: Altun, M. (2019). The Effect of Extra-Curricular Activities in Hizmet Movement Schools on Students' Personal Growth: A Case Study in Kurdistan Region, Iraq. International Journal of Academic Research in Business and Social Sciences, 9(2), 203-210.

Copyright: (C) 2019 The Author(s)

Published by Human Resource Management Academic Research Society (www.hrmars.com) This article is published under the Creative Commons Attribution (CC BY 4.0) license. Anyone may reproduce, distribute, translate and create derivative works of this article (for both commercial and non-commercial purposes), subject to full attribution to the original publication and authors. The full terms of this license may be seen at: $\underline{\text { http://creativecommons.org/licences/by/4.0/legalcode }}$

Vol. 9, No. 2, 2019, Pg. 203 - 210

http://hrmars.com/index.php/pages/detail/IJARBSS

JOURNAL HOMEPAGE

Full Terms \& Conditions of access and use can be found at http://hrmars.com/index.php/pages/detail/publication-ethics 


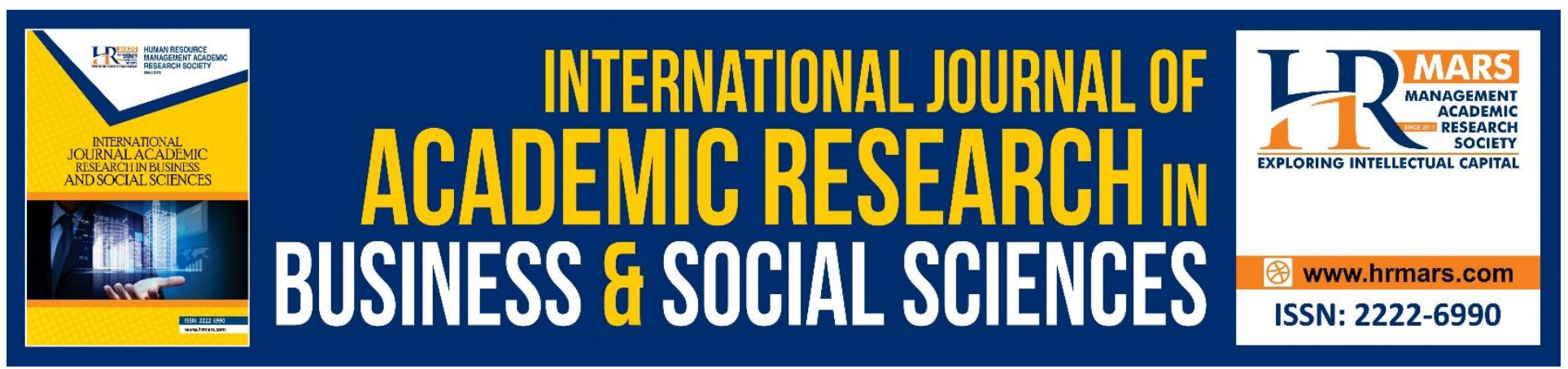

\title{
The Effect of Extra-Curricular Activities in Hizmet Movement Schools on Students' Personal Growth: A Case Study in Kurdistan Region, Iraq
}

\author{
Mustafa Altun, PhD \\ Department of English Language Teaching, Ishik University, Erbil, Iraq \\ Email: mustafa.altun@ishik.edu.iq
}

\begin{abstract}
It should be emphasized that the role of schools is not only to transmit the knowledge, but also educate students morally as well. In Hizmet Movement schools (HMS), the intellectual and spiritual development of students holds a prominent place. Teachers in HMS are inspired to generate students with high morals and distinguished virtues, as well as excellent intellectual capabilities. This paper explorers the dual role of teachers in HMS as transmitters of knowledge and builders of good character. The paper particularly investigates the role of extra-curricular activities carried out by teachers in HMS in forming the ideal human character.
\end{abstract}

Keywords: Extra-Curricular Activities, Teacher-Student Relationship, Teacher Commitment, Hizmet Movement Schools

\section{INTRODUCTION}

Extra-curricular activities (ECA) are actions that take place outside regular class teaching and yet are linked to student learning. As such, they come within the reach of the school curriculum. If there are suitable schools, great managers and volunteer teachers to spend their time with students an amazing masterpiece appears.

Chan and Ming (2015) state that "extra-curricular activities take care of students' different developmental needs, such as their sense of moral values and attitudes, skills and creativity" (p.1). The primary effect concerns student behavior. Research suggests that participation in extra-curricular activities decrease behavior problems associated with students.

Wilson (2009) argued that "along with understanding the benefits of being involved in extracurricular activities, students and parents may cultivate a concern as to how academic and nonacademic activities can be balanced in a manner benefit to adolescents" (p.9). In the engagement of extracurricular activities, academic benchmarks may be set in order for student eligibility in sports and activity participation. This form of Wilson (2009) "eligibility may motivate students to do their 
best academically in order to participate in the activity" (p.10). In the case of difficulties situation which may arise, students can receive help from fellow friends from within and outside the school environment, or even sports coaches can assist them. In the content of extracurricular activities, students are given the ability to make interaction with others, form friendships, and to cultivate better social self-esteem. Furthermore, participation might be "interpreted as a sign of maturity and as a self-affirming behavior"

\section{Hizmet Movement Schools (HMS)}

Hizmet is a civil society movement which originated as a religious congregation in the 1960s' and 70s' in Turkey. The 1980s witnessed the birth of a few private high schools in major Turkish cities. By the early 1990s, these schools had evolved into a nationwide education community. By the 2000s it had become a transnational social movement, with over two thousand non-denominational schools, dialogue organizations, and relief charities and media outlets in over 160 countries worldwide. It is faith-inspired in its motivation yet faith-neutral or inclusive in its manifestation, demonstrating the type of religion-secularity mentioned above.

HMS proposes to provide education with high standards and embrace local as well as universal values. Boyd (2006) reported that "the education in Gulen schools is modern (scientific). This extraordinary excellent, and ethically focused education is couched in a milieu of what is called by Gulen universal values", such that students depart from the system as rather extraordinary human beings, committed to such values as hard work, honesty, humility, compassion and service to the global community. (p.1)

The foundation provides educational services to the entire community regardless of religion, ethnicity, social condition or political ideas. HMS contributes to the culture of peaceful coexistence in their respective localities. In this teaching model, the schools provide secular education in conformity with the national curriculum. The schools welcome students from all cultural, spiritual, ethnic settings, and display them to a rich experience thanks to their pluralistic environment. They also use graphics technology and pedagogical tools for scientific and technological invention. HMS aims to raise qualified individuals equipped with the necessary language, writing, artistic and thinking skills to be the agents of sustainable development in their regions.

\section{Hizmet Movement Schools (HMS) in Iraq}

In Kurdistan Region of Iraq, there are Hizmet Movement schools (HMS) that are locally registered under Fezalar Educational Company. This educational company was established in Erbil city at the beginning of the year 1994 by a group of Turkish and Iraqi investors and educators.

HMS currently serves the Iraqi society with 35 schools, ranging from kindergarten to University levels, distributed in Kurdistan Region, as well as in Kirkuk, Baghdad and Basra. All HMS operates under the jurisdiction of and are regularly inspected by the central government of Iraq and of the Kurdistan Regional Government. Those schools are taking on the official curriculum wherever they go, with a 
majority of the subjects taught in English along with some Turkish. There is no special religious content, except the compulsory religion classes stipulated by the Ministry of Education.

\section{Hizmet Movement}

The founder of Hizmet Movement, Muhammad Fethullah Gülen, cleric and writer of more than 60 books, teaches a peaceful, spiritual and dialogic form of Islam, and recognizes democracy as the best kind of governance. In his educational views, Eldridge "Gülen envisions a world where people are deeply grounded in a moral and ethical tradition, here humility and service are highly valued and where reason, science and technology are fully utilized for the benefit of all" (p. 526)

As for the role of teachers in HMS, Gülen believes (2014) that

Teachers should know how to find a way to the student's heart and be able to leave indelible imprints upon his or her mind. They should test the information to be passed on to students by refining their own minds and the prisms of their hearts. A good lesson is one that does more than provide pupils with useful information or skills; it should elevate them into the presence of the unknown. (p. 209)

Thousands of teachers who follow Gülen's guidance live far away from their families. They hence have the chance to spend their leisure times with students after the lessons, having an amazing discussion around a cup of tea or arranging an interesting event which students be dying to do it. (ECAs) are a part of the curriculum to advance a wide range of learning from their teachers.

Nelson (2014) reported that "Gülen-inspired teachers prefer to teach ethics by example rather than through lecture in order not to create conflict between themselves and community expectations." (p.1)

\section{EXTRA CURRICULAR}

Simply put, Extracurricular activities are activities in which students participate outside of both school hours and curriculum. T.W. Hong (2000) reported that the quality of school education relates not just to academic knowledge, but also to the attitudes, skills and values which schools help students to develop. (p.16) They are hence not formally marked in student grades and are generally, though not in all contexts, participated voluntarily. They are evident in all levels of our school. These numerous forms include sports such as football or tennis, clubs such as chess club or drama club, governance, school newspaper, student radio, music, art, and so forth. According to Lunnenburg (2010), extracurricular actives cultivate a similar role as the obligatory components of a school curriculum yet provide new experiences and offerings that formal curriculum cannot provide. Furthermore, these new experiences can be applied within and out of the school context, benefiting both their academic and social lives. Massoni (2011) as such, summaries the overall effects of extra-curricular actives as better behavior, grades, school completion, and positive attitudes to attain success.

In the HMS context, the formally crafted extra-curricular activities department serves the overall ambition to develop students social, cultural, and behavioral development. It is believed that when students are left idle, they are susceptible to certain foreign dangers which may negatively affect 
their behavioral development. E. Bureau (2012) indicate that It is important to ensure that students enjoy a well-balanced school life through their participation in ECA (p.3). As such, this department aims to displace any such dilemmas by ensuring students are kept busy and active. Essential to this is the strong relationship that designated guidance counselors construct with their students. The list of activities that are conduced are vast. They can be a simple as enjoying a cup of tea with students in their lunch break, to weekly football programs and weekly camps. Providing activities that are enjoyable and creative will allow students' eagerness to join such programs. Every single activity conducted will aim in one way or another to pass on some sort of learning. For example, a tea session may involve a small discussion about respect in parents. This way, the student can enjoy the session from an entertainment perspective, and the guidance counselor will be able to successfully achieve the main aim of extra-curricular activities, which is not to merely entertain students, but pass on some form of learning for the overall development of the student.

\section{The Research Context}

The purpose of this study is to investigate the impact of extra-curricular activities in HMS on students' personal growth. Preliminarily students who graduated from HMS and those who study currently participated study. The data collection tool used for this research was a questionnaire. The questionnaire consisted of 10 questions. While the first five questions were designed to reveal the contribution of extra-curricular activities to the personal growth of the students, the last five questions were designed to investigate the influence of these activities on creating an ideal society member. Totally over 100 students participated in this research. 50 of them are alumni and the other 50 are still students in HMS in Iraq Kurdistan region. We visited the alumni either at home or in their work places and asked them to fill in the survey questionnaire. Similarly, Hizmet Movement schools in Iraq were visited by the researcher and upon approval of the school administration, the students were asked to fill in the survey questionnaire in the classroom. It took for the researcher a total of six months to collect the needed data from the students.

\section{Research Questions}

1. Do extracurricular activities impact on the development personal growth?

2. Do extracurricular activities help create better ideal society members?

\section{Data Collection}

In this study survey data collection technique has been used. The data in this research has been analyzed through SPSS program. Participants are either graduates or current students. The data was collected at the beginning of 2018 in Fezalar boys and girls' schools which have been providing education for more than 20 years in Iraq. Also, data were collected from graduates who work in Iraq in different companies, organizations and institutions. 


\section{Findings}

Table 1: Responses by the students to the questions

\begin{tabular}{|l|l|l|l|l|l|l|}
\hline & $\begin{array}{l}\text { Strongly } \\
\text { disagree }\end{array}$ & Disagree & Neutral & Agree & $\begin{array}{l}\text { Strongly } \\
\text { agree }\end{array}$ & Total \\
\hline Q1 & 1 & 0 & 15 & 22 & 42 & 80 \\
\hline Q2 & 0 & 3 & 12 & 34 & 31 & 80 \\
\hline Q3 & 0 & 6 & 5 & 39 & 30 & 80 \\
\hline Q4 & 0 & 1 & 12 & 17 & 30 & 80 \\
\hline Q5 & 0 & 3 & 17 & 26 & 34 & 80 \\
\hline Q6 & 2 & 1 & 20 & 29 & 28 & 80 \\
\hline Q7 & 1 & 3 & 13 & 22 & 41 & 80 \\
\hline Q8 & 0 & 1 & 9 & 37 & 33 & 80 \\
\hline
\end{tabular}

Table 1 demonstrates that responses of the students to all questions heavily weighted on the positive side which means the students favored the use of extracurricular activities for their academic personal growth. When the responses are analyzed, it is evidently seen that the students showed strong preference towards extracurricular activities for allowing them to enhance personal development. While 64 students indicated that extracurricular activities were part of their lives, only 1 student indicated otherwise. 15 students had no ideas. 65 students saw the benefits of extracurricular activities for promoting positive attitudes. 69 students agreed that these activities help them keep away from unhealthy habits. 47 students agreed that extracurricular activities aided them to develop good hobbies. 60 students stated that these activities are useful in that they will have a strong sense of belonging. 57 students agreed that these activities stimulated them to like their subject matter courses and similarly, 63 students were of the opinion that the use of extracurricular activities at schools promote academic achievement of students. And 70 students reported agreement that extracurricular activities help them build good relationships with others.

Table 2: Frequency distribution

\begin{tabular}{|l|l|l|l|l|l|l|}
\hline & $\begin{array}{l}\text { Strongly } \\
\text { disagree }\end{array}$ & Disagree & Neutral & Agree & $\begin{array}{l}\text { Strongly } \\
\text { agree }\end{array}$ & Total \\
\hline Q1 & $\% 0$ & $\% 0$ & $\% 18.8$ & $\% 30.0$ & $\% 50.0$ & $\% 100$ \\
\hline Q2 & $\% 0$ & $\% 3.8$ & $\% 15.0$ & $\% 42.5$ & $\% 38.8$ & $\% 100$ \\
\hline Q3 & $\% 0$ & $\% 7.5$ & $\% 6.3$ & $\% 48.8$ & $\% 37.5$ & $\% 100$ \\
\hline Q4 & $\% 0$ & $\% 1.3$ & $\% 15.0$ & $\% 46.3$ & $\% 37.5$ & $\% 100$ \\
\hline Q5 & $\% 0$ & $\% 3.8$ & $\% 21.3$ & $\% 32.5$ & $\% 42.5$ & $\% 100$ \\
\hline Q6 & $\% 2.5$ & $\% 1.3$ & $\% 25.0$ & $\% 36.3$ & $\% 35.0$ & $\% 100$ \\
\hline Q7 & $\% 1.3$ & $\% 3.8$ & $\% 16.3$ & $\% 51.2$ & $\% 27.5$ & $\% 100$ \\
\hline Q8 & $\% 0$ & $\% 2.5$ & $\% 25.0$ & $\% 42.5$ & $\% 30.0$ & $\% 100$ \\
\hline
\end{tabular}




\section{Discussion}

It is obvious that ECAs has huge impact on students' personal growth. Bakoban and Aljarallah (2015) mentioned that "Extracurricular activities (ECA) are part of students' everyday life; they play important roles in student's lives". It is evidently seen in the questionnaire that a great number of the participants stated agreement that ECA implemented at school greatly helped them with personal development. These activities have the potential to better students' lives as they set good examples for the students. Students will not only perform activities but at the same time they will learn what to do and how to behave in certain situations. For instance, an activity concerning aiding poor people will not only help students spend their time in a useful way but also make them understand the needy people better. Furthermore, ECAs create good relationship between students and teachers. It is possible to say that the relationship between students and teachers encourage students to accomplish better. Avci and Doghonadze (2017) argue that, the interaction between teacher and students creates motivation and inspiration which are considered as significant elements in effective learning.

\section{Conclusion}

ECAs are activities that take place during school time and after school. ECAs offer huge opportunities for teachers to shape students' character because for students they create a natural learning environment. Also for parents it is doubtless that their children are busy with useful activities. ECAs encourage students to communicate with classmates and express themselves bravely in a social life. It is clear that ECAs inspire students' creation, motivation, and many other aspects that he/she may use in their future life. Students develop personal growth as long as they are involved in activities which are for this purpose. ECAs are activities which are designed to help them gain better personal skills. This study shows that ECAs are useful activities which should be widely used in educational settings as their influence on students' personal development cannot be underestimated.

\section{References}

Chan, T. M. K., \& Ng, S. W. (2015). Management of Outsourcing Extra-Curricular Activities in Primary Schools: Issues and Considerations. International Studies in Educational Administration (Commonwealth Council for Educational Administration \& Management (CCEAM)), 43(1).

Wilson, N. (2009). Impact of extracurricular activities on students. Unpublished thesis). University of Wisconsin-Stout, England. Retrieved from www2. uwstout. edu/content/lib/thesis/2009/2009wilsonn. pdf.

Boyd, B. S. (2006, November). A Comparison: The Wisdom Of Fethullah Gülen And The Truth of Parker Palmer. Enlightened Education As A Key To Global Transformation. In Islam In The Contemporary World-3. The Fethullah Gülen Movement in Thought and Practice: Conference Paper, Norman, Oklahoma, USA, University of Oklahoma (pp. 77-86).

Eldridge, B. (2007). The place of the Gülen movement in the intellectual history of Islam, particularly in relation to Islam's confrontation with postmodernism. Muslim World in Transition, 526-38. 
Gülen, M. F. (2014). Love and Tolerance. Işık Yayıncılık Ticaret.

Tsang, W. H. (2000). Quality management of extracurricular activities in Hong Kong secondary schools (Doctoral dissertation, Education).

Nelson, C. (2005). Fethullah Gülen: A vision of transcendent education. Accessed on, 7(18), 2008.

Lunenburg, F. C. (2010). Extracurricular activities. Schooling, v1, (1), p1-4.

Massoni, E. (2011). Positive effects of extra-curricular activities on students. Essai, 9(1), 27.

Bureau, E. (2012). Guidelines on Extra-curricular Activities in Schools.

Bakoban, R. A., \& Aljarallah, S. A. (2015). Extracurricular Activities and Their Effect on the Student's Grade Point Average: Statistical Study. Educational Research and Reviews, 10(20), 2737-2744.

Avci, R., \& Doghonadze, N. (2017). The Challenges of Teaching EFL Listening in Iraqi (Kurdistan Region) Universities. Universal Journal of Educational Research, 5(11), 1995-2004. 